\title{
PENGARUH STRUKTUR MODAL TERHADAP EARNING PER SHARE PADA PT TELEKOMUNIKASI INDONESIA TBK
}

\author{
Siti Maimunah $^{*)}$ dan Tiara Shinta Megasatya ${ }^{* *}$
}

\begin{abstract}
ABSTRAK
Setiap perusahaan selalu membutuhkan dana atau modal dalam rangka memenuhi kebutuhan operasi sehari-hari maupun untuk mengembangkan perusahaan. Dalam melakukan keputusan pendanaan, perusahaan dituntut untuk mempertimbangkan dan menganalisis sumber-sumber dan ekonomis guna membelanjai kebutuhan investasi serta kegiatan usahanya. Keputusan pendanaan ini akan mempengaruhi keadaan struktur modal perusahaan. Investor dan kreditur menggunakan informasi struktur modal sebagai ukuran pendanaan perusahaan. Penelitian ini bertujuan untuk menguji secara empiris pengaruh struktur modal terhadap earning per share. Berdasarkan hasil penelitian dan uji statistik yang telah dilakukan, variabel debt to asset ratio secara parsial tidak berpengaruh terhadap earning per share. Karena dari output uji t menunjukan bahwa hasil koefisien regresi variabel debt to asset ratio yaitu 2,042. Nilai ini lebih kecil dari nilai t tabel yaitu sebesar 2,0796. Dan variabel debt to equity ratio secara parsial berpengaruh terhadap earning per share. Karena berdasarkan output uji t menunjukkan hasil koefisien regresi variabel debt to equity ratio yang dihasilkan yaitu -3,998. Nilai ini lebih kecil dari nilai t tabel yaitu sebesar -2,0796. Kemudian Berdasarkan output uji statistik F secara bersama-sama (simultan) variabel independen (debt to asset ratio dan debt to equity ratio) memiliki pengaruh terhadap earning per share. Hal ini dapat dibuktikan dengan nilai $\mathrm{F}$ hitung yang dihasilkan sebesar 22,302 lebih besar dari $\mathrm{F}$ tabel yaitu 3,47 dan dapat disimpulkan bahwa struktur modal (debt to asset ratio dan debt to equity ratio) secara simultan atau bersama-sama berpengaruh terhadap earning per share.
\end{abstract}

Kata kunci: Debt to Asset Ratio, Debt to Equity Ratio, dan Earnings per Share

\begin{abstract}
Each company is always needed of funds or capital in order to get the needs of daily operations as well as to develop the company. In conducting the funding decision, the company is required to consider and analyze the sources and economically in order to finance the investment needs as well as business activities. The funding decisions will affect the company's capital structure. Investors and creditors use information as a measure funding the capital structure of the company. The purpose of this research was to test empirically the influence of capital structure to earnings per share. Based on the results of research and statistical tests that have been done, variable debt to asset ratio is partially no effect on earnings per share. Because of output t test showed that the results of the regression coefficient of variable debt to asset ratio is 2.042. This value is smaller than t table that is equal to 2.0796. And variable debt to equity ratio is partially an effect on earnings per share. Because based on output t test showed the results of the regression coefficient of variable debt to equity ratio produced is -3.998 . This value is smaller than t table that is equal to -2.0796. Then Based on statistical test output F together (simultaneously) the independent variable (debt to asset ratio and debt to equity ratio) have an effect on earnings per share. This can be proven by the calculated $F$ value generated at 22.302 larger than $F$ table is 3,47 and it can be concluded that the capital structure (debt to asset ratio and debt to equity ratio) simultaneously or jointly effect on earnings per share.
\end{abstract}

Key words: Debt to Asset Ratio, Debt to Equity Ratio, dan Earnings per Share

\footnotetext{
${ }^{*}$ Dosen Tetap Fakultas Ekonomi Universitas Pakuan

${ }^{* *}$ Mahasiswa Fakultas Ekonomi Universitas Pakuan
} 


\section{Pendahuluan}

Setiap perusahaan selalu membutuhkan dana atau modal dalam rangka memenuhi kebutuhan operasi sehari-hari maupun untuk mengembangkan perusahaan. Kebutuhan modal tersebut berupa modal kerja maupun pembelian aset tetap. Untuk memenuhi kebutuhan dana tersebut perusahaan harus mampu mencari sumber dana dengan komposisi yang menghasilkan biaya paling murah.

Alternatif dalam pemilihan sumber dana bagi perusahaan pada akhirnya akan menentukan struktur modal pada perusahaan. Baik buruknya struktur modal akan mempunyai efek langsung terhadap posisi dan stabilitas keuangan perusahaan. Hadi Susanto (2011) mengungkapkan kebijakan struktur modal berkaitan dengan trade-off antara risiko dan tingkat pengembalian. Pada umumnya, pendanaan melalui utang dalam struktur modal perusahaan akan memperbesar bunga tetapi sekaligus juga memperbesar tingkat pengembalian yang diharapkan. Penggunaan ekuitas dalam struktur modal perusahaan juga mengandung konsekuensi baik positif maupun negatif. Namun sebagaimana diketahui fenomena yang ada menujukkan bahwa penerbitan ekuitas banyak dilakukan oleh perusahaan publik tidak terkecuali di Indonesia.

Dalam melakukan keputusan pendanaan, perusahaan dituntut untuk mempertimbangkan dan menganalisis sumber-sumber dan ekonomis guna membelanjai kebutuhan investasi serta kegiatan usahanya. Keputusan pendanaan ini akan mempengaruhi keadaan struktur modal perusahaan serta mampu memberikan kemakmuran bukan hanya kepada stockholders tetapi juga kepada stakeholders secara keseluruhan. Keuntungan yang diperoleh harus lebih besar dari biaya modal. Maka penentuan kebijakan struktur modal akan mempengaruhi ruang lingkup kerja perusahaan.

Dalam penelitian ini penulis menggunakan dua jenis analisis rasio struktur modal, yaitu debt to asset ratio (DAR) dan debt to equity ratio (DER). Debt to asset ratio (DAR) digunakan untuk mengukur besarnya dana yang berasal dari utang, sedangkan debt to equity ratio (DER) untuk mengukur imbangan antara utang yang dimiliki perusahaan dengan ekuitas.

Tujuan perusahaan adalah meningkatkan kemakmuran para pemegang saham atau pemilik. Kemakmuran para pemegang saham diperlihatkan dalam wujud semakin tinggi harga saham, yang merupakan pencerminan dari keputusan-keputusan investasi, pendanaan, dan kebijakan dividen.

Earning per share (EPS) adalah jumlah pendapatan yang diperoleh dalam satu periode untuk tiap lembar saham yang beredar. Informasi EPS suatu perusahan menunjukan besarnya laba bersih perusahan yang siap dibagikan bagi semua pemegang saham perusahaan.

Oleh karena itu perusahaan harus mempunyai struktur modal yang optimal yaitu struktur modal yang dapat menghasilkan laba yang optimal, supaya dividen yang dibagikan kepada pemegang saham meningkat yang pada akhirnya kemakmuran para pemegang saham pun tercapai yaitu meningkatkan laba per lembar saham. Oleh karena itu kemakmuran para pemegang saham dapat dijadikan sebagai dasar analisis dan tindakan rasional dalam proses pembuatan keputusan. Kadang-kadang memaksimumkan laba dicanangkan sebagai tujuan perusahaan, akan tetapi hal itu tidak dapat mencapai sasaran memaksimalkan kemakmuran para pemegang saham. Yang lebih penting 
bukanlah laba melainkan laba per lembar saham. Laba didapatkan dengan mengurangkan dengan biaya yang dikeluarkan, sehingga untuk meningkatkan bisa dengan menarik modal baru (mengeluarkan saham baru), dan menginvestasikan dana yang diperoleh tersebut pada investasi yang bebas risiko (misalkan deposito atau obligasi pemerintah). Jika keuntungan memang meningkat, tetapi nilai saham justru akan menurun. Demikian pula halnya memaksimumkan laba per lembar saham (earning per share) bukan merupakan tujuan utama, karena tidak memperlihatkan waktu maupun lamanya laba yang diharapkan, juga tidak memperlihatkan faktor risiko maupun ketidakpastian di masa yang akan datang, serta tidak mempertimbangkan kemampuan perusahaan dalam membagi dividen.

Tujuan penelitian secara spesifik adalah untuk memperoleh jawaban dari permasalahan yang teridentifikasi di atas, yaitu untuk: 1) Untuk mengetahui pengaruh debt to asset ratio terhadap earning per share pada PT Telekomunikasi Indonesia Tbk tahun 2009-2014; 2) Untuk mengetahui pengaruh debt to equity ratio terhadap earning per share pada PT Telekomunikasi Indonesia Tbk tahun 2009-2014; dan 3) Untuk mengetahui pengaruh struktur modal (debt to asset ratio dan debt to equity ratio) terhadap earning per share pada PT Telekomunikasi Indonesia Tbk tahun 2009-2014.

\section{Landasan Teori}

\subsection{Struktur Modal}

Struktur modal merupakan komposisi pendanaan antara ekuitas (pendanaan sendiri) dan utang pada suatu perusahaan (Wild, et al., 2010). Sedangkan menurut Weston (2010) struktur modal adalah pembiayaan permanen yang terdiri dari utang jangka panjang, saham preferen, dan modal pemegang saham. Nilai buku dari modal pemegang saham terdiri dari saham biasa, modal disetor atau surplus modal, dan akumulasi modal ditahan.

Menurut Riyanto (2011) ada beberapa faktor yang mempengaruhi struktur modal, yaitu:

1. Tingkat bunga yang berlaku saat manajemen akan menentukan struktur modal akan mempengaruhi jenis modal yang akan digunakan apakah memakai saham atau obligasi;

2. Stabilitas dan besarnya earning yang diperoleh perusahaan akan menentukan apakah perusahaan dibenarkan menggunakan utang tetap atau tidak;

3. Pada kebanyakan industri atau manufaktur di mana sebagian besar modalnya tertanan dalam aset tetap akan cenderung menggunakan modal sendiri dibandingkan dengan modal asing atau hutang hanya sebagai pelengkap;

4. Risiko yang melekat kepada setiap aset belum tentu sama. Semakin panjang jangka waktu penggunaannya maka risiko semakin besar.

5. Jumlah modal yang diperlukan atau dibutuhkan akan mempengaruhi struktur modal. Jika modal yang dibutuhkan adalah besar maka dirasakan perlu bagi perusahaan untuk menggunakan sekuritas secara bersamaan;

6. Kondisi pasar modal sering mengalami perubahan yang disebabkan oleh berbagai faktor. Oleh karena itu, dalam rangka memperoleh dana melalui penjualan sekuritas perusahaan harus memperhatikan kondisi pasar modal; 
7. Bagi manajemen yang optimis akan masa depan perusahaan akan berani menanggung risiko besar sehingga akan lebih menggunakan hutang untuk memenuhi kebutuhan dana perusahaan.

8. Perusahaan yang besar di mana sahamnya tersebar sangat luas, penambahan saham untuk memenuhi kebutuhan dana tidak banyak mempengaruhi kekuasaan atau pengendalian pemegang saham mayoritas. Perusahaan besar pada umumnya lebih menyukai penerbitan saham baru dalam memenuhi kebutuhan dananya.

\subsection{Earnings per Share (EPS)}

Menurut Irham Fahmi dan Yofi Lavianti Hadi $(2011,77)$ EPS atau laba bersih per lembar saham adalah bentuk pemberian keuntungan yang diberikan kepada para pemegang saham dari setiap lembar saham yang dimiliki. EPS Rp100 artinya tiap lembar saham menghasilkan laba bersih Rp 100. Carilah perusahaan yang EPS-nya meningkat dari waktu ke waktu (tren positif). EPS yang menanjak menunjukkan bahwa perusahaan bertumbuh dengan baik yang artinya kemungkinan besar penjualan dan laba naik.

Ada pun rumus EPS adalah:

$$
\text { Earnings after tax }
$$

$\overline{\text { (lembar saham yang diterbitkan }}$

\section{Metode Penelitian}

Metode analisis yang digunakan dalam penelitian ini adalah regresi linier berganda untuk melihat ada tidaknya pengaruh variabel independen (struktur modal) terhadap variabel dependen (earning per share), yakni melalui pengujian regresi berganda, uji $t$, dan uji F. Untuk mempermudah pengolahan data maka penulis menggunakan bantuan SPSS versi 20.

\section{Hasil Penelitian dan Interpretasi Hasil Penelitian}

1. Uji Regresi Linier Berganda Analisis regresi linier berganda digunakan untuk menentukan seberapa besar pengaruh variabel independen terhadap variabel dependennya.

Tabel 1

Analisis Regresi Linier Berganda

Multiple Linear Regression Analysis Coefficients $^{\mathrm{a}}$

\begin{tabular}{|l|r|r|r|r|r|}
\hline \multirow{2}{*}{ Model } & \multicolumn{2}{|c|}{$\begin{array}{c}\text { Unstandardized } \\
\text { Coefficients }\end{array}$} & $\begin{array}{c}\text { Standardized } \\
\text { Coefficients }\end{array}$ & \multirow{2}{*}{ Sig. } \\
\cline { 2 - 4 } & \multicolumn{1}{|c|}{$\mathrm{B}$} & Std. Error & \multicolumn{1}{c|}{ Beta } & & \\
\hline (Constant) & 88.940 & 128.396 & & .693 & .496 \\
1 DAR & 9.093 & 4.453 & .776 & 2.042 & .054 \\
DER & -3.327 & .832 & -1.519 & -3.998 & .001 \\
\hline
\end{tabular}

a. Dependent Variable: EPS

(Sumber: Hasil pengolahan data dengan SPSS 20)

Berdasarkan tabel di atas, dapat diketahui nilai konstanta dan koefisien regresi untuk masingmasing variabel independen yang akan digunakan untuk menyusun persamaan regresi sebagaimana disajikan berikut ini:

$\mathrm{Y}=\mathrm{a}+\mathrm{b}_{1} \mathrm{X}_{1}-\mathrm{b}_{2} \mathrm{X}_{2}$

$\mathrm{Y}=88,940+9,093 \mathrm{DAR}-3,327 \mathrm{DER}$ 
Keterangan:

$\mathrm{Y}=$ Earning Per Share (EPS)

$\mathrm{X}_{1}=$ Debt to Asset Ratio (DAR)

$\mathrm{X}_{2}=$ Debt to Equity Ratio (DER)

Dengan nilai konstanta sebesar 88.940 artinya bahwa jika nilai dari variabel independen sebesar 0 (tidak berubah) maka earning per share sebesar 88.940 satuan. Dengan nilai koefisien regresi untuk variabel DAR (X1) sebesar 9.093 berarti jika DAR naik sebesar 1 satuan maka earning per share akan naik sebesar 9.093 satuan. Dengan nilai koefisien regresi untuk variabel DER (X2) sebesar -3.327 berarti jika DER naik sebesar 1 satuan maka earning per share akan turun sebesar 3.327 satuan.

\section{Uji Koefisien Determinasi dan Korelasi}

Uji determinasi atau ketepatan perkiraan model (goodness of fit) bertujuan untuk mengukur seberapa jauh kemampuan model dalam menerangkan variabel dependen.

Tabel 2

Uji Koefisien Determinasi dan Korelasi

Determination and Correlation Coefficient Test

Model Summary ${ }^{\mathrm{b}}$

\begin{tabular}{|l|r|r|r|c|}
\hline Model & $\mathrm{R}$ & $\mathrm{R}$ Square & $\begin{array}{c}\text { Adjusted R } \\
\text { Square }\end{array}$ & $\begin{array}{c}\text { Std. Error of the } \\
\text { Estimate }\end{array}$ \\
\hline 1 & $.825^{\mathrm{a}}$ & .680 & .649 & 31.562 \\
\hline
\end{tabular}

a. Predictors: (Constant), DER, DAR

b. Dependent Variable: EPS

(Sumber: Hasil pengolahan data dengan SPSS 20)

Angka $R$ yang didapat yaitu 0,825 , artinya korelasi antara variabel Debt to Asset Ratio dan Debt to Equity Ratio terhadap Earning Per Share sebesar 0,825 . Hal ini berarti terjadi hubungan yang erat karena nilai mendekati satu. Nilai $\mathrm{R}^{2}$ sebesar 0,680 artinya presentase sumbangan pengaruh variabel Debt to Asset Ratio dan Debt to Equity Ratio terhadap earning per share sebesar $68 \%$ sedangkan sisanya sebesar $32 \%$ dipengaruhi oleh variabel lain yang tidak dimasukkan dalam model penelitian ini.

\section{Uji Koefisien Regresi Secara Parsial (Uji t)}

Pengujian ini dilakukan untuk mengetahui apakah variabel independen (DAR dan DER) mempunyai pengaruh secara parsial atau tidak terhadap variabel dependen (earning per share).

Tabel 3

Uji t

T Test

Coefficients $^{\mathrm{a}}$

\begin{tabular}{|c|c|c|c|c|c|}
\hline \multirow[t]{2}{*}{ Model } & \multicolumn{2}{|c|}{$\begin{array}{c}\text { Unstandardized } \\
\text { Coefficients }\end{array}$} & $\begin{array}{l}\text { Standardized } \\
\text { Coefficients }\end{array}$ & \multirow[t]{2}{*}{$\mathrm{t}$} & \multirow[t]{2}{*}{ Sig. } \\
\hline & $\mathrm{B}$ & Std. Error & Beta & & \\
\hline (Constant) & 88.940 & 128.396 & & .693 & .496 \\
\hline
\end{tabular}




\begin{tabular}{|l|r|r|r|r|r|}
\hline DAR & 9.093 & 4.453 & .776 & 2.042 & .054 \\
DER & -3.327 & .832 & -1.519 & -3.998 & .001 \\
\hline
\end{tabular}

a. Dependent Variable: EPS

(Sumber: Hasil pengolahan data dengan SPSS 20)

Berdasarkan hasil uji t di atas, diperoleh $\mathrm{t}$ hitung DAR terhadap earning per share adalah sebesar 2,042. Karena nilai t hitung $(2,042)<$ $\mathrm{t}$ tabel (2,0796) maka dapat disimpulkan bahwa DAR secara parsial tidak berpengaruh terhadap earning per share. Untuk t hitung DER terhadap earning per share adalah sebesar $-3,998$. Karena nilai t hitung $(-3,998)<\mathrm{t}$ tabel $(-2,0796)$ maka dapat disimpulkan bahwa DER secara parsial berpengaruh terhadap earning per share.

\section{Uji Regresi Linier Berganda Secara Simultan (Uji F)}

Uji $\mathrm{F}$ digunakan untuk menguji keberartian pengaruh dari seluruh variabel independen secara bersamasama terhadap variabel dependen.

Tabel 4

Uji F

Table 4

F Test

ANOVA $^{\text {a }}$

\begin{tabular}{|r|r|r|r|r|r|}
\hline \multicolumn{1}{|c|}{ Model } & Sum of Squares & \multicolumn{1}{c|}{ df } & Mean Square & \multicolumn{1}{c|}{ F } & \multicolumn{1}{c|}{ Sig. } \\
\hline \multirow{2}{*}{1 Regression } & 44432.557 & 2 & 22216.278 & 22.302 & $.000^{\mathrm{b}}$ \\
Residual & 20919.402 & 21 & 996.162 & & \\
Total & 65351.958 & 23 & & & \\
\hline
\end{tabular}

a. Dependent Variable: EPS

b. Predictors: (Constant), DER, DAR

(Sumber: Hasil pengolahan data dengan SPSS 20)

Berdasarkan hasil uji F di atas, diperoleh F hitung sebesar 22,302. Karena nilai F hitung $(22,302)>$ F tabel $(3,47)$ maka dapat disimpulkan bahwa DAR dan DER secara bersama-sama berpengaruh terhadap earning per share.

\section{Interpretasi Hasil Penelitian}

a. Pengaruh Debt to Asset Ratio Terhadap Earning Per Share

Berdasarkan hasil penelitian ini, debt to asset ratio tidak memiliki pengaruh terhadap earning per share. Debt to asset ratio menggambarkan kemampuan aset perusahaan dibiayai utang. Debt to asset ratio digunakan untuk mengukur total utang dengan total aset. Jadi, apabila debt to asset ratio mengalami kenaikan maka tidak akan berpengaruh pada earning per share.

b. Pengaruh Debt to Equity Ratio Terhadap Earning Per Share

Berdasarkan hasil penelitian ini, debt to equity ratio memiliki pengaruh terhadap earning per share. Debt to equity ratio digunakan untuk menilai utang dengan ekuitas. Jadi, apabila debt to equity ratio mengalami kenaikan maka akan berpengaruh pada earning per share. 


\section{Penutup}

Setelah melakukan analisis dan pengujian hipotesis tentang pengaruh struktur modal terhadap earning per share pada PT Telekomunikasi Indonesia Tbk tahun 2009-2014, maka dapat diambil beberapa kesimpulan, yaitu:

1. Struktur modal pada PT Telekomunikasi Indonesia Tbk yang diukur dengan rasio DAR dan DER.

a. Debt to asset ratio (DAR) pada PT Telekomunikasi Indonesia Tbk tahun 2009-2014 masih cenderung fluktuatif. Nilai DAR terendah diperoleh pada tahun 2014 triwulan pertama yaitu sebesar $36,75 \%$, sedangkan nilai DAR tertinggi diperoleh pada tahun 2009 triwulan kedua yaitu sebesar $54,76 \%$. Nilai DAR semakin rendah menunjukkan total utang lebih kecil dibanding total asetnya dan kondisi ini semakin baik bagi perusahaan karena semakin kecil risiko ketidakmampuan perusahaan dalam melunasi utangnya.

b. Debt to equity ratio (DER) pada PT Telekomunikasi Indonesia Tbk tahun 2009-2014 cenderung menurun. Jika di lihat per triwulan data debt to equity ratio selalu meningkat pada triwulan kedua dan mengalami penurunan kembali pada triwulan berikutnya. Dapat disimpulkan bahwa nilai DER yang semakin rendah dikarenakan total utang lebih kecil dari total ekuitas dan hal ini merupakan kondisi yang baik bagi perusahaan karena perusahaan memiliki risiko yang kecil dalam ketidakmampuan melunasi hutangnya melalui ekuitas.

2. Earning per share (EPS) pada PT Telekomunikasi Indonesia Tbk dari tahun 2009-2014 cukup baik dan cenderung meningkat. Nilai earning per share tertinggi sebesar Rp289 pada tahun 2014 triwulan ketiga dan nilai earning per share terendah sebesar Rp101 pada tahun 2009 triwulan keempat. Nilai earning per share yang semakin meningkat tentu saja menggembirakan pemegang saham karena semakin besar laba yang disediakan untuk pemegang saham.

3. Secara parsial, variabel Debt to Asset Ratio (DAR) tidak memiliki pengaruh terhadap Earning Per Share pada PT Telekomunikasi Indonesia Tbk, maka hipotesis 1 tidak terbukti. Hasil penelitian ini konsisten dengan penelitian yang dilakukan oleh Ranika Purnawidya Primasari (2012) dan Andriyani Br. Girsang (2011) yang menyatakan bahwa secara parsial Debt to Asset Ratio (DAR) tidak memiliki pengaruh terhadap Earning Per Share.

4. Secara parsial, variabel Debt to Equity Ratio (DER) memiliki pengaruh terhadap Earning Per Share pada PT Telekomunikasi Indonesia Tbk, maka hipotesis 2 terbukti. Hasil penelitian ini konsisten dengan penelitian yang dilakukan oleh Yeni Limiati (2007) yang menyatakan bahwa secara parsial Debt to Equity Ratio (DER) memiliki pengaruh terhadap Earning Per Share.

5. Secara simultan, Debt to Asset Ratio (DAR) dan Debt to Equity Ratio (DER) berpengaruh signifikan terhadap Earning Per Share pada PT Telekomunikasi Indonesia Tbk. Hal ini menunjukkan bahwa hipotesis 3 terbukti. Hasil penelitian ini sesuai dengan penelitian yang dilakukan oleh Yeni Limiati (2007), yang menyatakan bahwa Debt to Asset Ratio (DAR) dan Debt to Equity Ratio (DER) berpengaruh signifikan terhadap Earning Per Share. 
6. Melalui Uji Koefisien Determinasi $\left(\mathrm{R}^{2}\right)$, sebesar $68 \%$ earning per share dipengaruhi oleh struktur modal (Debt to Asset Ratio dan Debt to Equity Ratio), sedangkan sisanya sebesar $32 \%$ dipengaruhi oleh variabel lain yang tidak termasuk dalam model regresi. Sedangkan hasil penelitian berdasarkan uji statistik secara simultan (bersama-sama) bahwa struktur modal berpengaruh terhadap earning per share.

\section{Daftar Pustaka}

Ahmad Syafi'i Syakur. 2009. Intermediate Accounting Dalam Perspektif Lebih Luas Edisi 1. Jakarta: AV Publisher.

Andriyani Br Girsang. 2011. Pengaruh Struktur Modal Terhadap Earning Per Share Pada Perusahaan Yang Terdaftar Di Indeks Kompas 100. Skripsi Program Sarjana Universitas Telkom, Bandung.

Bambang Riyanto. 2011. Dasar-dasar Pembelanjaan Perusahaan Edisi 4. Yogyakarta: BPFE.

Brigham, Eugene F. dan Joel F. Houston. 2011. Dasar-dasar Manajemen Keuangan Jilid II. Jakarta: Salemba Empat.

Dermawan Sjahrial. 2010. Manajemen Keuangan (Edisi 4). Jakarta: Mitra Wacana Media.

Dewi Utari, Ari Purwanti, dan Darsono Prawironegoro. 2014. Manajemen Keuangan: Kajian Praktek dan Teori dalam Mengelola Keuangan Organisasi Perusahaan (Edisi Revisi). Jakarta: Mitra Wacana Media.

Duwi Priyatno. 2012. Cara Kilat Belajar Analisis Data Dengan SPSS 20. Yogyakarta: Andi Publisher.

Elisa Purwitasari. 2013. Analisis Pengaruh Struktur Modal Terhadap Profitabilitas (Studi
Empiris pada Perusahaan Manufaktur yang Terdaftar di Bursa Efek Indonesia Tahun 20092011). Skripsi Program Sarjana Universitas Diponegoro, Semarang.

Elok Sri Utami. 2012. Strategi Pendanaan Antara Utang dan Saham. Malang: Universitas Brawijaya.

Gitman, Lawrence J. and Chad J. Zutter. 2011. Principles of Managerial Finance $13^{\text {th }}$ Edition. Boston: Pearson Education Inc.

Gruber, H. 2005. The Economics of Mobile Telecommunications. Cambridge: Cambridge University Press.

Hadi Susanto. 2011. Jurnal Vol.5, No.1: Struktur Kepemilikan Saham dan Kondisi Keuangan Perusahaan Pengaruhnya Terhadap Kebijakan Hutang. Surabaya: Universitas Wijaya Putra.

Imam Ghozali. 2011. Aplikasi Analisis Multivariate Dengan Program SPSS. Semarang: BP Universitas Diponegoro.

Iman Muhammad. 2006. Pengaruh Struktur Modal Terhadap Harga Saham Perusahaan Obat-obatan Terbuka di Bursa Efek Jakarta. Tesis Program Pasca Sarjana Universitas Terbuka, Medan.

Irham Fahmi dan Yovi Lavanti Hadi. 2011. Teori Portofolio dan Analisis Investasi: Teori dan Soal Jawab. Penerbit Alfabeta, Bandung.

Keown, Arthur J., John D. Martin, J. William Petty, dan David E. Scott, Jr. 2011. Manajemen Keuangan: Prinsip dan Penerapan, Jilid 1. Jakarta: Indeks.

Kieso, Donald E., Jerry J. Weygandt, dan Terry D. Warfield. 2009. Akuntansi Intermediate Jilid 2. Jakarta: Erlangga. 
Lukman Syamsuddin. 2011. Manajemen Keuangan Perusahaan. Konsep Aplikasi dalam: Perencanaan, Pengawasan, dan Pengambilan Keputusan (Edisi Baru). Jakarta: Rajawali Pres.

Mamduh M. Hanafi dan Abdul Halim. 2009. Analisis Laporan Keuangan. Yogyakarta: UPP AMP YKPN.

Ranika Purnawidya Primasari. 2012. Pengaruh Struktur Modal Terhadap Earning Per Share (EPS) Pada Perusahaan Telekomunikasi di Indonesia Yang Sahamnya Telah Terdaftar di Bursa Efek Indonesia. Skripsi Program Sarjana Universitas Telkom, Bandung.

S. Munawir. 2010. Analisa Laporan Keuangan Edisi 4. Liberty.

Suad Husnan dan Enny Pudjiastuti. 2012. Dasar-dasar Manajemen Keuangan Edisi Ke 6. Yogyakarta: UPP STIM YKPN.

Sugiyono. 2013. Statistika Untuk Penelitian Cetakan Ke 23. Bandung: Alfabeta.

Sutrisno. 2013. Manajemen Keuangan Teori, Konsep, dan Aplikasi. Yogyakarta: Ekonisia.

Syofian Siregar. 2014. Metode Penelitian Kuantitatif SPSS. Yogyakarta: Prenada Media Grup.

Weston, Fred J. dan Thomas E. Copeland. 2010. Manajemen Keuangan Jilid 2. Jakarta: Binarupa Aksara Publisher.

Wild, John J. dan K. R. Subramanyam. 2010. Analisis Laporan Keuangan Edisi 10. Jakarta: Salemba Empat.

Yeni Limiati. 2007. Pengaruh Struktur Modal Terhadap Laba Per Lembar Saham Pada Kelompok Industri Farmasi. Skripsi Program Sarjana Universitas Widyatama, Bandung. 